\title{
Reflections on worker's compensation in the state of New Jersey
}

This article was published in the following Dove Press journal:

Medicolegal and Bioethics

29 April 2013

Number of times this article has been viewed

\section{Edward H Tobe \\ University of Medicine and Dentistry of New Jersey/School of Osteopathic Medicine, University of Medicine and Dentistry of New Jersey/Robert Wood Johnson Medical School, and Cooper Medical School of Rowan University, Camden, NJ, USA}

\begin{abstract}
A healthy, productive workforce improves the socioeconomic interests and stability of society. In the early 20th century, federal worker's compensation law was modified from intentional and unintentional negligence tort law to a no-fault system; this was designed to optimize the outcome of work-related injuries for both employers and employees. It was recognized that the integrity of the worker's health was essential to society. Each state independently legislated medical and fiscal management of occupational injuries and illness. The state of New Jersey presently has a system to evaluate the complex processes that the worker and worker's family experience after a work-related injury. The current legislation may encourage antipathy and mental regression during a vulnerable period of the worker's life. Reflecting on potential legislative shortcomings may stimulate ideas to create improved treatment outcomes.
\end{abstract}

Keywords: labor, law, injury, insurance, occupational medicine

\section{Introduction}

Occupational diseases, injuries, and deaths challenge the injured, families of the injured, and society. According to the New Jersey Department of Health and Senior Services, there were 78 workplace fatalities and 110,000 nonfatal occupational injuries and illnesses in the State of New Jersey in 2010. ${ }^{1}$ In the United States in 2010, there were 4690 work-related fatalities, and 1,191,100 work-related injuries and illnesses that caused lost time from work (Figures 1 and 2). ${ }^{2,3}$ Such statistics stimulate prudent queries about how to minimize negative sequelae from these injuries and illnesses and to promote recovery.

In a 2004 report by the World Health Organization Department of Mental Health and Substance Abuse, the importance of defining mental health was described as follows:

[...] a state of well-being in which the individual realizes his or her own abilities, can cope with the normal stresses of life, can work productively and fruitfully, and is able to make a contribution to his or her community[.] ${ }^{4}$

There is an important relationship between mental and physical health, and joint promotion of mental and physical health can help bring lives to fruition. A bifurcation of mental and physical health undermines the effectiveness of the physician. 5,6 Occupational injuries may affect mental health, and mental health may affect recovery from occupational injury.
Correspondence: Edward H Tobe I00I Lincoln Drive West Suite B, Marlton, New Jersey 08053-1534, USA

Tel +l 8569834940

Email edward.tobe@comcast.net 


\section{Cause of 4690 fatal US work injuries}

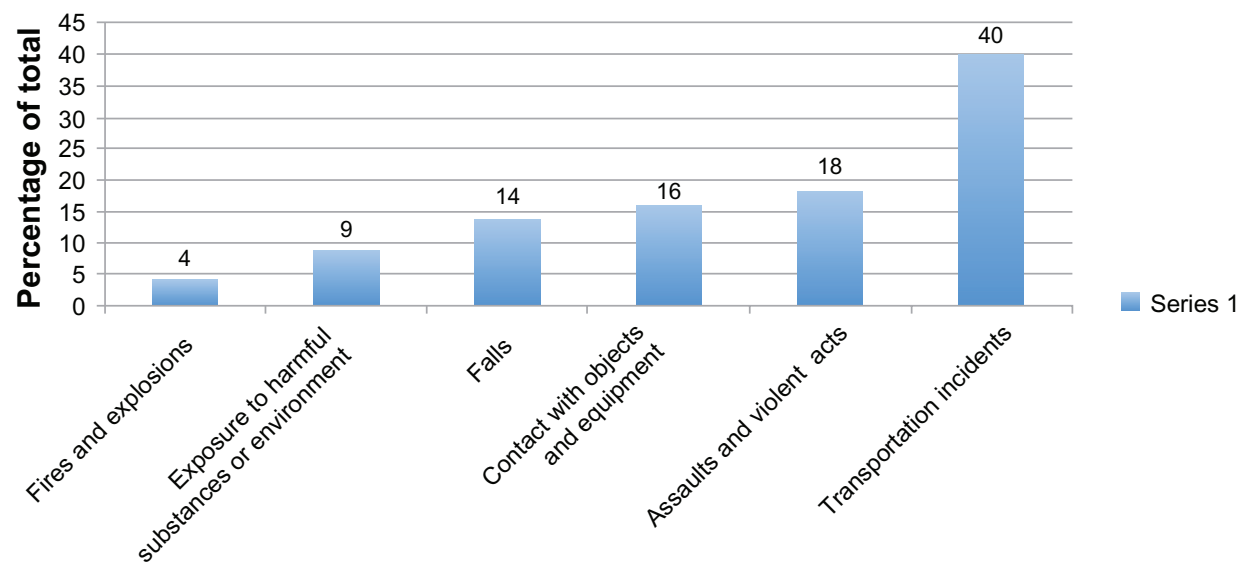

Figure I Work fatalities in the United States 2010

Note: Data from the Bureau of Labor Statistics, United States Department of Labor, 2012. ${ }^{2}$

The purpose of this article is to review the intent of worker's compensation laws in the United States, selected portions of New Jersey worker's compensation legislation, the relationship between occupational injury and mental health, and the effect of worker's compensation legislation on mental health providers and their patients.

\section{Historical overview}

Technological developments in the United States as a result of the Industrial Revolution included the railroad system, coal mining, steel production, and various kinds of machinery. Industry valued productivity, and intentional and negligent tort laws protected employers. Accidents were cheap, and workers were expendable. ${ }^{7}$ Many laborers were hardworking immigrants, and cultural differences frequently alienated immigrant workers from the local population. ${ }^{7}$ Adversarial relations between worker and employer potentially created labor unrest.

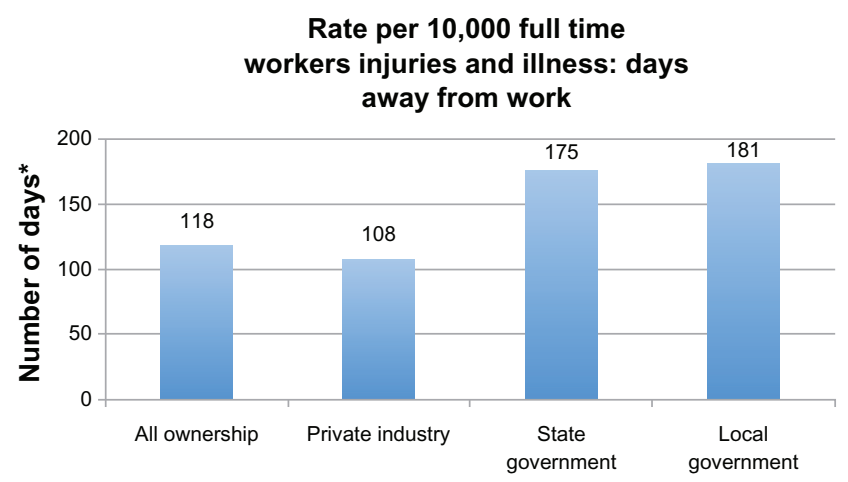

Figure 2 Relationship between ownership of workplace and frequency of days away from work caused by non-fatal work injuries in the United States in 2010.

Notes: *Data reported as number of days away from work per 10,000 full time workers. I,191,000 non-fatal work injuries in the United States in 2010.

Data from the Bureau of Labor Statistics, United States Department of Labor, November 2011. ${ }^{3}$
Federal safety regulations were developed for various industries that acknowledged the importance of protecting the worker. The federal government and many states passed legislation to provide the injured worker with expedient treatment and economic assistance and shield the employer from liability. The United States Employees' Compensation Act sponsored by Senator John W Kern and Representative Daniel J McGillicuddy was signed into law in 1916 by President Woodrow Wilson. This act focused on economic losses of federal civil service employees. ${ }^{8}$

Worker's compensation legislation was challenged because the Fourteenth Amendment to the United States Constitution, ratified in 1868, provided due process protection. In 1917, the United States Supreme Court rendered an important decision in the case of New York Central Railway Company versus White, a night watchman who was killed during his work duties. Judge Piney wrote the majority decision and explained the constitutional concerns about the Employees' Compensation Act:

The scheme of the act is so wide a departure from commonlaw standards respecting the responsibility of employer to employee that doubts naturally have been raised respecting its constitutional validity. The adverse considerations urged or suggested in this case and in kindred cases submitted at the same time are: (a) that the employer's property is taken without due process of law, because he is subjected to a liability for compensation without regard to any neglect or default on his part or on the part of any other person for whom he is responsible, and in spite of the fact that the injury may be solely attributable to the fault of the employee; (b) that the employee's rights are interfered with, in that he is prevented from having compensation for injuries arising from the employer's fault commensurate with the damages 
actually sustained, and is limited to the measure of compensation prescribed by the act; and (c) that both employer and employee are deprived of their liberty to acquire property by being prevented from making such agreement as they choose respecting the terms of the employment. ${ }^{9}$

The court offered a very detailed assessment of the interface between worker's compensation and the Fourteenth Amendment of the United States Constitution and ruled that the New York State worker's compensation laws did not violate due process. ${ }^{9}$

\section{Disability definition in New Jersey law}

Disability impairs production by reducing the effective labor pool and generating costs of evaluation, treatment, and financial support. New Jersey worker's compensation legislation defines disability:

Disability permanent in quality and partial in character means a permanent impairment caused by a compensable accident or compensable occupational disease, based upon demonstrable objective medical evidence, which restricts the function of the body or of its members or organs; included in the criteria which shall be considered shall be whether there has been a lessening to a material degree of an employee's working ability. Subject to the above provisions, nothing in this definition shall be construed to preclude benefits to a worker who returns to work following a compensable accident even if there be no reduction in earnings. Injuries such as minor lacerations, minor contusions, minor sprains, and scars which do not constitute significant permanent disfigurement, and occupational disease of a minor nature such as mild dermatitis and mild bronchitis shall not constitute permanent disability within the meaning of this definition. ${ }^{10}$

\section{Practical problems for employer and employee}

The goal of worker's compensation insurers is profit for the insurance company. Insurers refuse non-contractual fiscal responsibility. The business of insuring worker injuries, medical costs, and disability payments is inherently complex. Providing medical evaluations and expensive radiologic studies for all workers who suffer a back injury would generate prohibitive costs and low-yield diagnostic findings. Pain varies widely among people with similar injuries, and complaints of pain may face credibility challenges under the standard of "demonstrable objective medical evidence." 10 The employer may avoid documenting a work injury because this may increase premiums or the supervisor may dislike the worker; consequently, the insurer may deny responsibility for the treatment of an undocumented injury.

The burden of proof of the validity of the worker's claim falls upon the worker. The injured worker may require representation by an attorney to negotiate with the insurer, motion the court for treatment, and prove the validity of the injury and its relation to work. If the worker misrepresents the cause of the medical problem to the commercial medical insurance, the worker jeopardizes the validity of the worker's compensation claim and creates an adversarial argument of dishonesty.

Malingering or false claims generate insurer costs. Malingering scales have many assumptions but fall short of "demonstrable objective medical evidence."10 In 508 consecutive chronic pain patients who were referred to a psychology department, the protocol of "malingered pain-related disability and malingered neurocognitive dysfunction" and "well validated indicators" showed that many patients were malingerers. ${ }^{11}$ The prevalence of malingering in patients with chronic pain and financial incentive was between $20 \%$ and $50 \% .{ }^{11}$ These results are vague and have a wide margin of error, and investigating malingering is costly. Clever malingerers may deceive experienced physicians. Hiring investigators to videotape the behavior of the injured worker is costly and open to interpretation.

\section{Adversarial problems}

The injured worker may question the neutrality and competence of the evaluating or treating physician because the law requires evaluation and treatment only through insurerdesignated, "authorized" health care providers. The few exceptions to this situation include care required because of a court order or medical emergency that needs immediate attention. Authorized providers report to the insurer and obtain approval from the insurer for treatment. The injured worker often perceives that the authorized provider is working for the insurance company.

Psychiatric evaluation or treatment can expose sensitive aspects of the worker's life that are not work-related. This sensitive information may be used to discredit the worker. The authorized psychiatrist or insurance company may conclude that the disability is caused by a history of childhood abuse and not the work-related accident. Claims adjusters can question the credibility of an injured worker, deny the insurer's authorized physician recommendations, and change authorized physicians. If the petitioner refuses the medical decision of the insurer, such as surgery, temporary medical 
benefits can be terminated on the basis of maximum medical improvement (MMI).

The interface between the insurer and injured worker (petitioner) may be complex and may necessitate legal representation for both parties. ${ }^{12}$ In New Jersey the injured worker's attorney files a claim petition with the Division of Workers' Compensation, Department of Labor and Workforce Development. The worker's attorney interfaces with the insurer, who corresponds with the adjuster or attorney for the insurer. Disagreements regarding authorizing treatment may prompt legal motions before the administrative law judge or a trial. Trials to decide motions for treatment and temporary disability payments require testimony from the injured worker and other lay witnesses and may require costly adversarial expert testimony. A court decision about the need for treatment may take many months. Economic vulnerability from loss of income may compromise the injured worker and the worker's family, which may compel forfeiture of treatment to obtain an economic resolution. This adversarial legal process is costly in lost time and legal expenses.

Attorneys for both the insurer and petitioner obtain Independent Medical Evaluations (IMEs) to clarify the need for treatment or to assess disability awards. The IMEs may not represent a consensus of medical opinion or the expert's singular opinion verifiable through standard textbooks or medical literature. The IME may be performed in an adversarial manner. To refuse an IME places the injured worker at risk of termination of benefits. ${ }^{10}$

When treatment concludes, two-thirds of the cases settle without a court trial. ${ }^{13}$ Disagreement about the amount of disability award is resolved through adversarial hearings with testimony from lay witnesses, the injured worker, and opposing experts. The court's determination of money award may require many months of trial while the injured worker and family face the realities of economic depletion and loss of home and vehicles, especially if the worker is not successfully reintegrated into the workplace. In 2008, there were 45 presiding judges of worker's compensation in New Jersey. ${ }^{13}$ The "comp court" runs on a calendar that allows each case to come before a judge only once each 3 weeks. ${ }^{13}$ Although judges may order treatment, payment of bills, payment of temporary disability, or interest on outstanding payments, the compensation judges do not have the authority to fine or jail people who ignore the orders. ${ }^{13}$

\section{Injured worker: vocational and economic instability}

Many families lack 6 months savings to withstand a financial crisis (Table 1). ${ }^{14}$ Fiscal uncertainty and instability
Table I Net worth of United States families in 2007

\begin{tabular}{|c|c|c|c|}
\hline \multirow{2}{*}{$\begin{array}{l}\text { Family } \\
\text { characteristic }\end{array}$} & \multicolumn{2}{|l|}{ Net worth } & \multirow{2}{*}{$\begin{array}{l}\text { Families that } \\
\text { saved (\%) }\end{array}$} \\
\hline & Mean $(\$ 1000)$ & Median $(\$ 1000)$ & \\
\hline All families & 556.3 & 120.3 & 56.5 \\
\hline \multicolumn{4}{|c|}{ Percentiles of income (2007 dollars) } \\
\hline \multicolumn{4}{|c|}{ Percentiles of net worth } \\
\hline$<25 \%$ & -2.3 & 1.2 & 40.4 \\
\hline $25 \%$ to $49.9 \%$ & 57.9 & 54.2 & 52.9 \\
\hline $50 \%$ to $74.9 \%$ & 227 & 219.8 & 59 \\
\hline $75 \%$ to $89.9 \%$ & 586.1 & 571.4 & 69 \\
\hline $90 \%$ to $100 \%$ & 3975.70 & 1890.70 & 80.2 \\
\hline
\end{tabular}

Note: Data from the Board of governors of the federal reserve system. 2007 Survey of Consumer Finances..$^{14}$

may negatively affect families and cause fear, interpersonal strife, and demoralization. When the patient reaches MMI, temporary medical benefits end immediately with no required warning. When no check arrives, the injured worker discovers that MMI was reached and that temporary medical benefits were terminated. If the worker cannot return to the same employer, because of medically determined work restrictions or job unavailability, employee medical benefits may be unaffordable. Some people have an effective social network and find new work, but others become marginalized. An injured worker who pursues vocational rehabilitation may be terminated from receiving temporary medical benefits from the insurer; the insurer may justify termination because of the fallacious argument that attending vocational rehabilitation is evidence that the worker can return to work.

\section{Risk of compromised medical outcome}

Treatment context such as physician empathy versus disinterest may affect medical outcome. Injury may threaten the worker's ability to provide food and shelter, and this may create fear and vulnerability. The initial interaction between the injured worker and the insurer's authorized medical personnel may influence attitudes of trust between provider and patient. If treatment is protracted or ineffectual, bilateral antipathy may develop between the insurance company's authorized doctor and the injured.

If an injured worker or the physician requests urgent medical intervention, but the insurer disagrees, there is a complex legal process:

Motion by worker for emergent medical treatment. When through medical documentation a physician states that a worker is in need of emergent medical care that is not, following a request by the worker to the employer or the employer's carrier, being provided or authorized by the 
employer, the worker may file a motion for emergent medical treatment with or after the filing of a claim petition. The physician shall further state that delay of treatment will result in irreparable harm or damage and state the specific nature of the irreparable harm or damage. The motion, to which shall be appended all medical records in possession of the moving party, shall also be served on the employer and the employer's carrier, or their attorneys, at the time of filing. An answer to the motion shall be filed not later than five calendar days after the date of service. An initial conference on the motion shall take place within five calendar days of the filing of the answer. Thereafter the judge of compensation shall schedule the matter for a hearing in accordance with the rules adopted pursuant to section 3 of this act. There shall be provided 15 calendar days from the date of service of the motion to secure a medical examination if it requires one. L.2008, c.96, s. $1 .^{10}$

Physicians reading this legislation recognize a potential medical disaster because of the delay in treatment. Although the law may create an appearance of fairness, progressive disease will aggravate the patient's condition.

When the authorized physician or expert IME examiner determines that the worker has reached MMI, treatment will end but the disease process may continue and reverse treatment gains. Treatment may be impeded by preexisting medical comorbidities such as diabetes mellitus, obesity, and cardiac, vascular, and pulmonary disease.

Although often ignored, psychiatric disorders may be among the most disabling nonfatal illnesses. Psychiatric comorbidities can become a major impediment to a successful outcome from physical injury or illness that causes disability. The National Epidemiologic Survey on Alcohol and Related Conditions showed that alcohol abuse affected 17.6 million adult Americans in 2001 to 2002. ${ }^{15}$ Emotional stress may aggravate or initiate drug and alcohol abuse. When physicians fail to explore the patient's psychiatric history, there is a serious risk that prescribed controlled dangerous substances will reawaken drug dependence. If family ties are compromised, the bartender may offer the only sympathetic ear. In addition, depression may cause major disease burden:

Major depression was estimated to be the leading cause of non-fatal burden in the world in 1990, accounting for $10.7 \%$ of totalYLD (years lived with disability). Correspondingly, it was the 4th leading cause of total disease burden, accounting for $3.7 \%$ of total DALYs (disability-adjusted life years) (1). In the Version 1 estimates for the Global Burden of Disease 2000 study, published in the World Health Report
2001 (2), unipolar depressive disorders remain the leading cause of YLDs, accounting for $11.9 \%$ of total global YLDs, and also remains the fourth leading cause of total disease burden, accounting for $4.4 \%$ of total DALYs. ${ }^{5}$

Many injured workers deny mood disorder because mental illness is perceived as a threat, and they may focus on pain as the major problem because pain is a normal signal for survival. However, chronic pain is a stress that compromises brain neuroplasticity. ${ }^{16-18}$ Mood disorders and chronic pain amplify each other, and the anergia of depression limits reintegration to the workforce. Depression impairs cognition through stress-induced alterations in the morphology and metabolism of the hippocampus in the brain. ${ }^{19,20}$

Regression, which is a retreat from an achieved level of mature adaptation, is a major threat to the injured worker's recovery. Regression commonly occurs in frightened people who do not have a strong support system. Many competent, proud tradespeople define themselves by their work. An impairing injury can devastate their personal identity, and subjectively they become a "nobody." A dependent individual wants the illusion of belonging to the workplace "family." If injured, the dependent worker assumes that the parent-like boss will express personal interest. The fracturing of this illusion causes righteous feelings of indignation, bitterness, and abandonment.

The medical profession historically has encouraged examining the patient in the context of the patient's life. A healthy mental state is associated with physical health, and despondency may impair the executive function of brain to the extent of suicide. ${ }^{21}$ The ancient Greek physician Hippocrates wrote: "Declare the past, diagnose the present, foretell the future; practice these acts. As to diseases, make a habit of two things: to help, or at least to do no harm."6 Therefore, optimal medical evaluation and treatment of the injured worker necessitates a study of the whole person.

\section{Conclusion and recommendations}

The stability and effectiveness of the work force enriches society. Legislative measures search for legal fairness but indirectly undermine the intent to enable and protect the injured and the employer. There is no ideal solution, and each state in the US has different worker's compensation legislation. Although there are legislative deficiencies, intervention by the New Jersey Division of Workers' Compensation may be effective for many injured workers. The purpose of a critical analysis of specific parts of the 
New Jersey worker's compensation legislation is to encourage reconsidering specific aspects of current legislation.

Mental regression may be prevented with rapid identification of the injured worker's difficulties, prompt treatment, and aggressive vocational rehabilitation. These measures also may discourage the malingerer. Rehabilitation may protect the competitiveness of the work force and improve family stability. Depending on the size and diversity of the company's jobs, if the employer cannot accommodate medically determined suggestions or limitations for the worker's current job, the employer may rehabilitate the worker to a new position. The employer's interest in the injured worker may diminish the worker's fears and may increase trust and loyalty within the employeremployee relationship.

Termination of benefits should not be punitive or precipitous. The attainment of MMI should be determined by a neutral medical opinion instead of the insurer's expert or authorized medical provider. After the injured worker reaches MMI, medically prudent treatment may be necessary to maintain treatment gains; this may require seamless transition to a "worker's compensation injury aftercare fund" that may reduce insurer cost and maintain the worker's improved state.

"Help, or at least to do no harm" requires empathic, objective health care providers. Antipathy created by an adversarial system plus hostile IMEs and contumely providers may increase costs by prompting litigation or injured worker's mental regression.

Psychiatric sequelae of work injuries may impair recovery. A rapid process of diagnosis, treatment, and rehabilitation may diminish the risk of hopelessness that promotes psychiatric illness. Multiple operations and chronic pain management may fail in the presence of an undiagnosed or untreated mental illness. If the brain is impaired, the treatment of the body is impaired. ${ }^{21}$ The World Health Organization provides international and regional consensus data indicating that mental illness such as untreated depression may profoundly disable people from participation in the workforce. ${ }^{22}$

Injured workers, insurers, employers, attorneys, and governments have financial goals and priorities. Conflicting interest between these parties can generate a costly, unproductive, adversarial, litigious environment that loses the focus of enabling the workforce and jeopardizes the success of social policy. The broader goal is to educate and maintain an internationally competitive labor force in the United States. Therefore, it may be beneficial to develop methods to integrate medical and vocational services outside the economic liabilities of the insurer.

\section{Disclosure}

EHT has no financial support in preparing this paper, no vested financial interests, and no connection to any research facility, pharmaceutical company, or government agency.

\section{References}

1. State of New Jersey Department of Health and Senior Services. Occupational health and safety statistics - New Jersey. Available from: http://nj.gov/health/ohs/njohstats.shtml. Accessed April 26, 2012.

2. Bureau of Labor Statistics, United States Department of Labor, 2012 Revisions to the 2010 Census of Fatal Occupational Injuries (CFOI) counts. http://www.bls.gov/iif/oshwc/cfoi/cfoi_revised10.pdf. Accessed February 26, 2013.

3. Bureau of Labor Statistics, United States Department of Labor, Nov 2011. Nonfatal occupational injuries and illnesses requiring days away from work, 2010. http://www.bls.gov/news.release/archives/ osh2_11092011.pdf. Accessed February 26, 2013.

4. Introduction. In: Herrman H, Saxena S, Moodie R, editors. Promoting Mental Health: Concepts, Emerging Evidence, Practice: Summary Report/A Report of the World Health Organization, Department of Mental Health and Substance Abuse in Collaboration with the Victorian Health Promotion Foundation and the University of Melbourne. Geneva, Switzerland: World Health Organization; 2004:12-15. Available from: http://www.who.int/mental_health/evidence/en/promoting_mhh.pdf. Accessed June 15, 2012.

5. Ayuso-Mateos JL. Global burden of unipolar depressive disorders in the year 2000. Available from: http://www.who.int/healthinfo/statistics/ bod_depression.pdf. Accessed June 22, 2012.

6. Hippocrates. Epidemics, book 1, section 11. In: On the Sacred Disease. Hippocrates 400 B.C.E.

7. Watson WE, Watson JF, Ahtes JH III, Schandelmeier EH III. The Ghosts of Duffy's cut: the Irish Who Died Building America's most Dangerous Stretch of Railroad. Santa Barbara, CA: ABC-CLIO/Praeger; 2006.

8. United States Congress. To pass H.R. 15316 (39 Stat 742, September 7, 1916), a bill to provide compensation for injuries of federal employees while in the performance of their duties and for other purposes (P 10916-10911). Available from: http://www.govtrack.us/congress/ votes/64-1/h87. Accessed June 22, 2012.

9. Justia.com. New York Central R Co $v$ White, 243 United States 188 (1917). Available from: http://supreme.justia.com/cases/federal/ us/243/188/. Accessed April 28, 2012.

10. Workers' Compensation Law Title 34, Chapter 15, Articles 1 to 10 , Inclusive (R.S. 34:15-1 to R.S. 34:15-142) as amended and supplemented. State of New Jersey Department of Labor and Workforce Development Division of Workers' Compensation. http://lwd.dol.state. nj.us/labor/forms_pdfs/wc/pdf/wc_law.pdf.

11. Greve KW, Ord JS, Bianchini KJ, Curtis KL. Prevalence of malingering in patients with chronic pain referred for psychologic evaluation in a medico-legal context. Arch Phys Med Rehabil. 2009;90(7):1117-1126.

12. New Jersey Division of Workers' Compensation Department of Labor and Workforce Development. A Worker's Guide to Workers' Compensation in New Jersey. Available from: http://lwd.dol.state.nj.us/labor/ forms_pdfs/wc/pdf/wc(g)-338.pdf. Accessed June 22, 2012.

13. Martin J. How Jersey fails injured workers. Available from: http://blog. nj.com/ledgerarchives/2008/06/how_jersey_fails_injured_worke.html. The Star Ledger June 12, 2008, updated October 02, 2009. Accessed March 22, 2013.

14. Board of Governors of the Federal Reserve System. 2007 Survey of Consumer Finances. Available from: ttp://www.federalreserve.gov/pubs/ oss/oss2/2007/scf2007home.html. Accessed March 27, 2013. 
15. Grant BF, Dawson DA, Stinson FS, Chou SP, Dufour MC, Pickering RP. The 12-month prevalence and trends in DSM-IV alcohol abuse and dependence: United States, 1991-1992 and 2001-2002. Drug Alcohol Depend. 2004;74(3):223-234.

16. Rigucci S, Serafini G, Pompili M, Kotzalidis GD, Tatarelli R. Anatomical and functional correlates in major depressive disorder: the contribution of neuroimaging studies. World J Biol Psychiatry. 2010; 11(2 Pt 2):165-180.

17. Rajkowska G, Miguel-Hidalgo JJ, Wei J, et al. Morphometric evidence for neuronal and glial prefrontal cell pathology in major depression. Biol Psychiatry. 1999;45(9):1085-1098.

18. McEwen BS. Glucocorticoids, depression, and mood disorders: structural remodeling in the brain. Metabolism. 2005;54(5 Suppl 1): $20-23$
19. Paré D. Role of the basolateral amygdala in memory consolidation. Prog Neurobiol. 2003;70(5):409-420.

20. Reznikov LR, Grillo CA, Piroli GG, Pasumarthi RK, Reagan LP, Fadel J. Acute stress-mediated increases in extracellular glutamate levels in the rat amygdala: differential effects of antidepressant treatment. Eur $J$ Neurosci. 2007;25(10):3109-3114.

21. Still AT. Abnormal and normal mentality. Andrew Taylor Still Papers. Kirksville, Missouri: Museum of Osteopathic Medicine. Available from: https://www.atsu.edu/museum/collections/index.htm. Accessed February 26, 2013.

22. World Health Organization. Mental health: depression. Available from: http://www.who.int/mental_health/management/depression/definition/ en/. Accessed April 27, 2012.
Medicolegal and Bioethics

\section{Publish your work in this journal}

Medicolegal and Bioethics is an international, peer-reviewed, open access journal exploring the application of law to medical and drug research and practice and the related ethical and moral considerations. The journal is characterized by the rapid reporting of reviews, case reports, guidelines and consensus statements, original research

\section{Dovepress}

and surveys. The manuscript management system is completely online and includes a very quick and fair peer-review system. Visit http://www.dovepress.com/testimonials.php to read real quotes from published authors. 